\title{
IMPLEMENTASI PEMBELAJARAN JARAK JAUH (PPJ) DALAM MENINGKATAN KEMANDIRIAN BELAJAR SISWA
}

\author{
Fathor Rozi \& Indria Firdausi Lana \\ Universitas Nurul Jadid \\ fathorrozi330@gmail.com \& indriafirdausilana16@gmail.com
}

\begin{abstract}
This study aims to describe the independence of Distance Learning learning in Madrasah Ibtidiyah students Nurul Iman Sindet Lami Besuk Probolinggo during the Covid-19 pandemic. This research uses a qualitative approach with case studies. The research method used is qualitative through observation, in-depth interviews, and field observations. The results showed that the application of learning using WAG (Whats App Group) as an online learning model in madrasah ibtidaiyah has the same steps for each teacher at Madrasah Ibtidaiyah Nurul Iman class VI by utilizing the menu on the WAG (WhatsApp Group), namely: video, voice, discussion, and demonstration. The implication of distance learning in madrasas is the best solution for all teachers in carrying out learning and is very conducive to the Covid-19 pandemic.
\end{abstract}

Keywords: Distance Learning, Independent Learning

\begin{abstract}
Abstrak: Penelitian ini bertujuan untuk mendeskripsikan kemandirian Pembelajaran Jarak Jauh belajar pada siswa Madrasah Ibtidiyah Nurul Iman Sindet Lami Besuk Probolinggo di masa pandemi Covid-19. Penelitian ini menggunakan pendekatan kualitatif dengan studi kasus. Metode penelitian yang digunakan adalah kualitatif melalui pengamatan, wawancara mendalam, dan observasi lapangan. Hasil penelitian menunjukkan bahwa penerapan pembelajaran dengan memanfaatkan WAG (WhatsApp Group) sebagai model pembelajaran daring di madrasah ibtidaiyah mempunyai langkah-langkah yang sama pada masing-masing guru di Madrasah Ibtidaiyah Nurul Iman kelas VI dengan memanfaatkan menu pada WAG (WhatsApp Group), yaitu: video, voice, diskusi, dan demonstrasi. Implikasi pembelajaran jarak jauh di madrasah menjadi solusi terbaik bagi semua guru dalam melaksanakan pembelajaran dan sangat kondusif pada masa pandemic covid-19.
\end{abstract}

Kata Kunci: Pembelajaran Jarak Jauh, Kemandirian Belajar

\section{PENDAHULUAN}

Munculnya wabah Covid-19 yang telah melanda lebih dari 200 negara di belahan dunia memberikan tantangan tersendiri bagi lembag-lembaga pendidikan, termasuk di Indonesia yang menimbulkan dampak cukup signifikan di berbagai bidang, termasuk

Fondatia : Jurnal Pendidikan Dasar

Volume 5, Nomor 1, Maret 2021; 109-124

https://ejournal.stitpn.ac.id/index.php/fondatia 
dalam dunia pendidikan '. Meningkatnya angka terpapar Covid-19, menyebabkan pemerintah melalui Menteri Pendidikan dan Kebudayaan mengeluarkan kebijakan agar sistem pembelajaran harus dilakukan dengan cara jarak jauh atau daring ${ }^{2}$. Pemerintah Provinsi serta Kabupaten, termasuk Pemerintah Kabupaten Probolinggo pula menetapkan kebijakan yang sama.

Pembelajaran jarak jauh sangat mengutamakan kepada kemandirian baik bagi guru maupun siswa. Guru bisa mengantarkan modul ajar kepada siswa nya tanpa harus bertatap muka secara langsung di dalam sesuatu ruangan yang sama ${ }^{3}$. Pembelajaran Jarak Jauh bisa dicoba dalam waktu yang sama ataupun berbeda. Pendidikan Jarak Jauh lebih bersifat efisien serta dikira sebagai paradigma yang sangat realistis. Tipe pembelajaran ini memakai media selaku perlengkapan interaksi antara guru serta siswa . Selanjutnya, bahan ataupun modul pelajaran dapat disajikan lewat media tersebut serta hendak dinilai/ evaluasi oleh guru.

Meskipun mempunyai beberapa keunggulan dalam praktiknya, tak dapat diabaikan bahwasanya pembelajaran jarak jauh juga memunculkan beragam problem yang seolah-olah menurunkan implementasi proses serta hasil pembelajaran. Permasalahan utama dalam Pembelajaran Jarak Jauh (PJJ) yaitu berhubungan dengan masalah teknis, seperti kurang mendukungnya akses penunjang, keterbatasan guru ketika melaksanakan Pembelajaran Jarak Jauh, dan persoalan lainnya. Salah satu faktor kurang maksimalnya implementasi Pembelajaran Jarak Jauh adalah anggapan bahwa guru merupakan salah satu sumber belajar sehingga pembelajaran berpusat pada guru (teacher centre) ${ }^{4}$. Keadaan inilah yang kemudian menimbulkan kesan bahwasanya pembelajaran hanya sebatas memahami dan mengulang sesuatu yang telah disajikan oleh guru dan berdampak pada rendahnya kemandirian siswa ${ }^{5}$. Kemandirian belajar ini menuntut tanggung jawab yang sangat besar

\footnotetext{
${ }^{1}$ Anggy Giri Prawiyogi and others, 'Efektifitas Pembelajaran Jarak Jauh Terhadap Pembelajaran Siswa Di SDIT Cendekia Purwakarta', Jurnal Pendidikan Dasar, 2020.

2 Chairiyaton Nabila Hilmy Zhafira, Yenny Ertika, 'Pembelajaran Jarak Jauh Di Masa Pandemi', Jurnal $l$ Bisnis Dan Kajian Strategi Manajemen, 2020.

3 Rodame Monitorir Napitupulu, 'Dampak Pandemi Covid-19 Terhadap Kepuasan Pembelajaran Jarak Jauh', Jurnal Inovasi Teknologi Pendidikan, 2020 <https://doi.org/10.21831/jitp.v7i1.32771>.

${ }^{4}$ Nadia Fairuza Azzahra, 'Mengkaji Hambatan Pembelajaran Jarak Jauh Di Indonesia Di Masa Pandemi Covid-19', Center for Indonesia Policy Studies, 2020.

${ }^{5}$ D R Sari and F Amrozi, 'Analisis Efektivitas Pembelajaran Jarak Jauh (PJJ) Di Politeknik Penerbangan Surabaya', Jurnal Penelitian, 2020.
} 
pada diri siswa . Peran guru maupun orangtua amat menentukan kelanjutan pendidikan mereka. Sehingga tidak ada sama sekali siswa yang terabaikan kegiatan belajarnya.

Kemandirian belajar menjadi syarat pokok dalam pelaksanaan pembelajaran jarak jauh ${ }^{6}$. Kemandirian belajar ditujukan kepada orang dewasa (andragogi) dengan memperhatikan empat konsep dasar di antaranya konsep diri, pengalaman, kesiapan belajar, dan perspektif terhadap waktu serta orientasi kepada belajar ${ }^{7}$. Siswa pada jenjang Madrasah Ibtidaiyah adalah siswa dengan rentang usia 7-12 tahun, yang mana usia ini juga merupakan usia yang masih membutuhkan banyak pengawasan dan pengayoman secara intens.

Penelitian ini dilaksanakan untuk memperoleh temuan empirik bagi usaha peningkatan kemandirian belajar siswa dengan mengimplementasikan pembelajaran jarak jauh di jenjang Madrasah Ibtidaiyah. Selain itu, kontribusi temuan penelitian terkait dengan implementasi pembelajaran jarak jauh ini akan menjadi daya tarik tersendiri bagi peneliti untuk melakukan penelitian ini.

Sejauh ini sudah banyak peneliti yang melakukan penelitian mengenai Pembelajaran Jarak Jauh, baik di masa sebelum Pandemi Covid-19 maupun sesudahnya, di antaranya adalah Hamidaturrohmah dan Tri Mulyani ${ }^{8}$. Dalam hasil penelitian terseut dijelaskan bahwa strategi Pembelajaran Jarak Jauh yang diterapkan di SD Inklusi Semai adalah pembelajaran 5M. Pertama, Memanusiakan hubungan dengan cara membangun relasi positif antara guru, siswa, dan orangtua. Kedua, Memahami Konsep dengan guru memandu belajar melalui penjelasan tujuan dan proses pembelajaran pada orangtua. Ketiga, Membangun keberlanjutan dengan melakukan refleksi bersama orangtua. Keempat, Memilih tantangan dengan memberikan ragam aktivitas pembelajaran sesuai dengan kebutuhan siswa . Kelima, Memberdayakan konteks dengan melibatkan sumber daya apa saja di rumah sebagai sumber belajar. Berikutnya adalah Dianne Amor Kusuma ${ }^{9}$

\footnotetext{
${ }^{6}$ Gatot Suharwoto, 'Pembelajaran Online Di Tengah Pandemi Covid-19, Tantangan Yang Mendewasakan', Times Indonesia, 2020.

${ }^{7}$ Ali Sadikin and Afreni Hamidah, Pembelajaran Daring Di Tengah Wabah Covid-19:(Online Learning in the Middle of the Covid-19 Pandemic)', BIODIK: Jurnal Ilmiah Pendidikan Biologi, 2020.

8 'STRATEGI PEMBELAJARAN JARAK JAUH SISWA BERKEBUTUHAN KHUSUS DI SD INKLUSI ERA PANDEMI COVID-19', ELEMENTARY: Islamic Teacher Journal, 2020.

9 'DAMPAK PENERAPAN PEMBELAJARAN DARING TERHADAP KEMANDIRIAN BELAJAR (SELF-REGULATED LEARNING) MAHASISWA PADA MATA KULIAH GEOMETRI SELAMA
} 
menjelaskan bahwa, meskipun mayoritas mahasiswa (95,8\%) sudah mempunyai perangkat untuk menjalani PJJ, namun di sisi yang lain mahasiswa merasa metode PJJ saat ini belum tepat karena mahasiswa merasa tidak dapat memantau perkembangan PJJ dengan mudah, tidak dapat memperoleh materi pembelajaran dengan mudah juga tidak dapat mempelajari materi dengan mudah. Secara keseluruhan, baik dari sisi teknologi maupun dari sisi tenaga pengajar, siswa tidak puas dengan metode PJJ yang dijalaninya saat ini dan juga merasa tidak puas dengan kemampuan dosen dalam menyampaikan materi pada PJJ. Yang terbaru adalah Afip Miftahul Basar ${ }^{10}$, yang menjelaskan bahwa proses Pembelajaran Jarak Jauh merupakan solusi yang dalam pelaksanaannya secara keseluruhan masih belum optimal. Ada hal yang harus diperhatikan dalam PJJ ini, antara lain sumber daya guru harus ditingkatkan mutunya, baik dari segi konten maupun metodologi juga dalam hal pemanfaatan teknologi informasi. Selain itu, siswa juga kurang aktif dalam mengikuti PJJ ini, baik itu disebabkan jaringan internet yang kurang stabil maupun dari segi penyediaan paket data internet yang begitu terbatas.

Dalam penelitian ini, pokok kajiannya adalah kemandirian belajar siswa di era Pandemi Covid-19 pada lembaga dasar, yaitu di Madrasah Ibtidaiyah. Pelaksanaan penelitian dilakukan di Madrasah Ibtidaiyah Nurul Iman yang berada di Desa Sindet Lami, Kecamatan Besuk, Kabupaten Probolinggo. Madrasah Ibtidaiyah Nurul Iman memberikan pelayanan ekstra kepada siswa nya dalam mengikuti Pembelajaran Jarah Jauh di masa Pandemi Covid-19, terutama kepada kelas VI untuk lebih aktif belajar meski dalam suasana Pandemi Covid-19. Hal ini dilakukan karena pimpinan dan seluruh tenaga pendidik tidak ingin siswa menyia-nyiakan waktu belajarnya menjelang kelulusan mereka. Pimpinan dan seluruh Madrasah Ibtidaiyah Nurul Iman merespon dengan memanfaatkan media pembelajaran yang bisa diakeses kapan saja, yaitu dengan menggunakan layanan internet melalui grup WA (WhatsApp Group).

Pembelajaran jarak jauh secara on line pada gilirannya menghilangkan rasa canggung yang pada puncaknya membuat siswa menjadi lebih berani untuk berekpresi dalam bertanya dan mengutarakan pendapatnya secara terbuka. Pembelajaran jarak jauh

PEMBELAJARAN JARAK JAUH DI MASA PANDEMI COVID-19', Teorema: Teori Dan Riset Matematika, $2020<$ https://doi.org/10.25157/teorema.v5i2.3504>.

10 'Problematika Pembelajaran Jarak Jauh Pada Masa Pandemi Covid-19', Edunesia: Jurnal Immiah Pendidikan, $2021<$ https://doi.org/10.51276/edu.v2i1.112>. 
juga mempunyai kelebihan tersendiri, yaitu mampu menumbuhkan kemandirian belajar atau "self regulated learning" siswa. Penggunaan aplikasi on line berupa WhatsApp Group (WAG) mampu meningkatkan kemandiri belajar.

Kekhawatiran akan terbengkalainya kegiatan pembelajaran tentu dibutuhkan kerja keras untuk menyelamatkan generasi dalam masa Pandemi Covid-19. Dari sana, keunikan penelitian ini adalah sebagai inisiatif perilaku suatu individu yang mampu dalam mengatasi berbagai masalah, mempunyai kepercayaan diri serta tidak menunggu arahan dari orang lain untuk belajar. Kemandirian belajar merupakan suatu kegiatan yang dilakukan oleh siswa tanpa mengandalkan orang lain untuk menguasai materi atau pengetahuan dengan kesadarannya sendiri serta dapat menerapkan pengetahuannya dalam menyelesaikan masalah.

Kemandirian belajar dalam penelitian ini diartikan sebagai kemampuan yang mengkondisikan siswa untuk dapat mempunyai karakter mandiri melalui belajar mandiri. Belajar mandiri adalah suatu proses belajar di mana individu bisa berinisiatif dengan atau tanpa bantuan orang lain ${ }^{11}$. Paradigma dalam penelitian ini adalah pandangan atau asumsi yang berdasarkan pelatihan dan pengalaman, kematangan psikologis, masalah yang dialami, dan faktor objek penelitian ${ }^{12}$. Atas dasar pemikiran tersebut, maka kerangka berpikir dalam penelitian ini difokuskan kepada pengaruh pembelajaran jarak jauh terhadap kemandirian belajar siswa . Pembelajaran jarak jauh adalah proses pembelajaran yang dilakukan secara tidak langsung yang bisa dilakukan melalui media internet.

Perkembangan teknologi dan informasi secara pesat pada saat ini secara langsung mendorong perkembangan pendidikan jarak jauh serta mendorong implementasi dalam pembelajaran. Dalam pembelajaran konvensional, siswa harus bertatap muka langsung dengan pendidik pada suatu tempat dan waktu yang sama. Hal ini berbanding dengan konsep dari Pembelajaran Jarak Jauh, di mana pelajar dan guru tidak perlu bertemu tatap

\footnotetext{
${ }^{11}$ Malcolm S Knowles, 'THE MODERN PRACTICE OF ADULT EDUCATION, From Pedagogy to Andragogy What Is Andragogy ?', Business, 1980.

12 J W Creswell, 'Creswell, J.W. (2003). Chapter One, “A Framework for Design.”, Research Design Qualitative Quantitative and Mixed Methods Approaches, 2003 <https://doi.org/10.3109/08941939.2012.723954>.
} 
muka untuk melakukan proses pembelajaran, dengan memanfaatkan teknologi proses pembelajaran dapat dilakukan ${ }^{13}$.

Kemandirian seorang siswa dapat dilihat dari kebiasaan yang mereka lalukan seperti merencanakan kegiatan belajar. Kemandirian belajar sangatlah penting karena berpengaruh terhadap terciptanya semangat diri untuk belajar ${ }^{14}$. Kemandirian belajar merupakan kesiapan dari individu yang mau dan mampu untuk belajar dengan inisiatif sendiri, dengan atau tanpa bantuan pihak lain dalam hal penentuan tujuan belajar, metoda belajar, dan evaluasi hasil belajar ${ }^{15}$. Berkaitan dengan hal tersebut, Sugilar merangkum pendapat Guglielmino, West \& Bentley bahwa kemandirian belajar merupakan kesiapan individu untuk mau dan mampu belajar dengan inisiatif sendiri meski tanpa bantuan pihak lain. Karakteristik individu yang mempunyai kesiapan belajar mandiri dicirikan dengan ${ }^{16}$ : a) Kecintaan terhadap belajar, b) Kepercayaan diri sebagai siswa , c) Keterbukaan terhadap tantangan belajar, d) Sifat ingin tahu, e) Pemahaman diri dalam keadaan belajar, f) Menerima tanggung jawab untuk kegiatan belajarnya.

Dalam kemandirian belajar, inisiatif merupakan indikator yang sangat mendasar ${ }^{17}$. Dalam pengertiannya yang lebih luas, kemandirian belajar mendeskripsikan sebuah proses di mana individu mengambil inisiatif sendiri, dengan atau tanpa bantuan orang lain, untuk mendiagnosis kebutuhan belajar, memformulasikan tujuan belajar, mengidentifikasi sumber belajar, memilih dan menentukan pendekatan strategi belajar, dan melakukan evaluasi hasil belajar yang dicapai.

Kemandirian belajar menuntut tanggung jawab yang besar pada diri peserta ajar sehingga peserta ajar berusaha melakukan berbagai kegiatan untuk tercapainya tujuan belajar. Kemandirian belajar sebagai bentuk belajar yang mempunyai tanggung jawab utama untuk merencanakan, melaksanakan, dan mengevaluasi usahanya. Dengan begitu,

${ }^{13}$ Sungkono Sungkono, 'PEMBELAJARAN JARAK JAUH BERBASIS TEKNOLOGI INFORMASI', MAJAL AH ILMLAH PEMBELAJARAN, 2005.

${ }^{14}$ Dede Rahmat Hidayat and others, 'KEMANDIRIAN BELAJAR SISWA DALAM PEMBELAJARAN DARING PADA MASA PANDEMI COVID -19 Program Studi Bimbingan Dan Konseling, Universitas Negeri Jakarta SELF-REGULATED LEARNING OF STUDENTS STUDYING ONLINE', PERSPEKTIF Ilmu Pendidikan, 2020.

${ }^{15}$ Yeni Rahmawati, 'Penerapan Model Pembelajaran Berbasis Masalah Untuk Meningkatkan Kemandirian Belajar Siswa', Fondatia, 1.1 (2017), 68-91 <https://doi.org/10.36088/fondatia.v1i1.89>.

16 (Zulfikar, 2020)

17 Sulastrini Sulastrini and Muslihati Muslihati, 'Rancangan Implementasi Kemandirian Belajar Dalam Konteks Pandemi Covid-19 Berdasarkan Perspektif Freedom to Learn Rogers', Prosiding Seminar Bimbingan Dan Konseling, 2020. 
kemandirian belajar perlu diberikan kepada peserta ajar susaha mereka mempunyai tanggung jawab dalam mengatur dan mendisiplinkan dirinya dalam mengembangkan kemampuan belajar atas kemauan sendiri ${ }^{18}$. Di samping tanggung jawab, motivasi yang tinggi dari siswa sangat diperlukan dalam kemandirian belajar. Lebih jauh lagi, dalam sistem belajar jarak jauh, motivasi memegang peranan sangat penting karena peserta ajar dituntut untuk belajar mandiri.

\section{METODE PENELITIAN}

Pelaksanaan penelitian dilakukan di Madrasah Ibtidaiyah Nurul Iman yang berada di Desa Sindet Lami, Kecamatan Besuk, Kabupaten Probolinggo. Metode penelitian yang digunakan ialah metode kualitatif. Metode kualitatif ialah metode yang bertumpu pada proses, bukan pada hasil. Jenis penelitian yang digunakan adalah studi kasus. Pesoalan yang mesti disempurnakan melalui penelitian ini ialah kemadirian siswa dalam mengikuti Pembelajaran Jarak Jauh (PJJ) semakin ditingkatkan.

Adapun teknik pengumpulan data dalam penelitian ini ialah melalui pengamatan, wawancara mendalam dan observasi lapangan. Setiap data yang diperoleh melalui proses pengamatan secara langsung. Pengamatan diperoleh berupa data atau keterangan mengenai kemandirian siswa dalam mengikuti Pembelajaran Jarak Jauh. Sumber data diperoleh melalui wawancara langsung dengan melakukan tanya jawab kepada pimpinan dan guru sebagai pendidik di Madrasah Ibtidaiyah Nurul Iman, Sindet Lami, Besuk, Probolinggo. Adapun data dalam penelitian ini ialah reduksi data, penyajian, dan penarikan kesimpulan.

Subjek penelitian adalah siswa yang duduk di bangku kelas VI. Dalam mengikuti Pembelajaran Jarak Jauh, dibutuhkan media pembelajaran yang bisa diakeses kapan saja dengan menggunakan layanan internet melalui grup WA (WhatsApp Group). Penelitian dilakukan dengan terlebih dahulu mengadakan survey kepada lembaga dan beberapa tenaga pendidik mengenai penerapan pembelajaran jarak jauh. Secara keseluruhan, siswa cukup puas dengan pembelajaran yang begitu fleksibel.

${ }^{18}$ Heni Jusuf, Ahmad Sobari, and Mohamad Fathoni, 'Pengaruh Pembelajaran Jarak Jauh Bagi Siswa SMA Di Era Covid-19', Jurnal Kajian Ilmiah, 2020 < https://doi.org/10.31599/jki.v1i1.212>. 


\section{HASIL DAN PEMBAHASAN}

Berdasarkan hasil penelitian dengan melakukan observasi dan wawancara yang telah peneliti uraikan, dapat dilihat bahwa cara guru dalam memanfaatkan WAG (WhatsApp Group) sebagai model pembelajaran daring cukup beragam. Pola pemanfaatan WAG (WhatsApp Group) ini bagi guru yaitu sebagai bahan rujukan dalam kegiatan pembelajaran, mengembangkan bahan ajar serta media pembelajaran di dalam kelas. Setiap guru bebas dalam berinovasi dan berkreasi dalam memanfaatkan menu WhatsApp sesuai dengan kebutuhan dan situasi belajar siswa .

Dengan memanfaatkan WAG (WhatsApp Group) sebagai media pembelajaran daring (online) dalam proses pembelajaran di kelas berarti guru telah melaksanakan kompetensi literasi digital dan teknologi kepada siswa . Keadaan ini sesuai dengan yang diharapkan dalam pendidikan di era revolusi industri 4.0 yaitu generasi yang melek teknologi dan internet.

Penerapan pembelajaran dengan perangkat daring (online) juga sejalan dengan adanya Permendikbud Nomor 68 Tahun 2014 tentang pendidik TIK dan pendidik keterampilan komputer dan pengelolaan informasi dalam implementasi kurikulum 2013 dan Permendikbud Nomor 119 Tahun 2014 tentang penyelenggaraan Pendidikan Jarak Jauh (PJJ) pada jenjang pendidikan dasar dan menengah ${ }^{19}$.

Melalui berbagai layanan menu dalam WAG (WhatsApp Group) ini terdiri dari video, voice, diskusi, dan demonstrasi, guru mengharapkan proses pembelajaran di luar kelas akan menjadi lebih kontekstual, bervariatif, menarik, efisien dan menyenangkan. Sebagaimana yang disampaikan oleh Chaidar Husain "bahwa kemajuan teknologi dan pemanfaatan internet menjadi acuan dunia pendidikan Indonesia sejak tahun 2013, Kemendikbud sudah mengembangkan kurikulum baru dan sistem yang semuanya serba di-online-kan serta mengembangkan pendidikan menuju masa depan Indonesia Emas di tahun 2045 nanti" 20.

\footnotetext{
${ }^{19}$ Ahmad Cucus and Yuthsi Aprilinda, 'Pengembangan E-Learning Berbasis Multimedia Untuk Efektivitas Pembelajaran Jarak Jauh', Explore: Jurnal Sistem Informasi Dan Telematika, 2016 $<$ https://doi.org/10.36448/jsit.v7i1.765>.

${ }^{20}$ Husain Chaidar, 'Pemanfaatan Teknologi Informasi Dan Komunikasi Dalam Pembelajaran Di SMA Muhammadiyah Tarakan', Jurnal Kebijakan Dan Pengembangan Pendidikan, 2.2 (2014), 184-92.
} 
Dengan adanya pemanfaatan WAG (WhatsApp Group) yang dilakukan oleh guru di madrasah, siswa diharapkan bisa mengakses kembali materi yang telah atau akan dipelajari melalui handphone ketika berada di rumah. Sehingga siswa merasa nyaman dalam belajarnya.

Hasil penelitian yang dilakukan pada bulan Januari sampai Februari 2021 di Madrasah Ibtidaiyah Nurul Iman, Sindet Lami, Besuk menunjukkan bahwa terdapat berbagai cara yang dilakukan oleh para guru dalam memanfaatkan WAG (WhatsApp Group) sebagai media pembelajaran yang lebih efektif. Pembelajaran dengan menggunakan WAG yang sudah dilakukan oleh guru tentunya merupakan suatu usaha yang cukup realistis mengingat pembelajaran langsung tidak diperkenankan.

Untuk meningkatkan minat dan bakat serta suasana belajar yang kondusif dan menyenangkan, guru memaksimalkan WAG. Pembelajaran dengan memanfaatkan jaringan internet pada HP dapat dilaksanakan manakala guru tersebut mempunyai kompetensi yang baik dan bisa memahami bahwa peran utama seorang guru bukan sekedar mengajar, akan tetapi juga menciptakan lingkungan belajar yang kondusif dan menyenangkan bagi siswa nya ${ }^{21}$. Berpijak pada hasil observasi dan wawancara, menu yang sering dimanfaatkan guru dalam proses pembelajaran yaitu video dan diskusi.

Sementara untuk menu lainnya guru belum pernah mencobakan dalam proses pembelajaran karena masih dalam tahapan mempelajari lebih lanjut dan merencakan sesuai dengan materi yang dibutuhkan pada pembelajaran. Guru mengaku tidak mengalami kesulitan sama sekali ketika mengaplikasikan keempat menu tersebut karena materi yang diperlukan sudah dikelompokkan berdasarkan kelas, mata pelajaran dan topik yang telah ditentukan. Keadaan ini sangatlah memudahkan guru dalam memilah dan menyeleksi materi yang sesuai dengan tujuan pembelajaran yang ingin dicapai oleh siswa .

Seluruh materi yang disampaikan tentu mengacu pada buku ajar yang telah disediakan sebelumnya di buku-buku paket dari pemerintah. Dengan video, guru lebih leluasa menjelaskan materi. Hal ini disampaikan oleh Iis Dewi Lestari bahwa "menu yang paling sering dimanfaatkan guru sebagai media pembelajaran dari daring yaitu video. Video

${ }^{21}$ Hasan Baharun and others, 'Learning Strategies for Mobile-Assisted Seamless Learning: A Students ' Initial Perceptions', 536.Icsteir 2020 (2021), 557-60. 
merupakan menu yang bisa menjelaskan berbagai konten pembelajaran seperti audio, animasi, visual dan audio visual. ${ }^{22}$,

Guru memanfaatkan BSE dikarenakan tidak semua siswa mempunyai buku cetak dan apabila terdapat materi yang perlu dijelaskan melalui gambar dari buku-buku tersebut. Dengan demikian media lainnya yang sering dimanfaatkan adalah BSE (Buku Sekolah Elektronik) dan Kolom Soal melalui google drive. BSE adalah buku-buku yang disediakan dalam bentuk file PDF elektronik yang bisa diunduh, dicetak, bahkan diperbanyak oleh siapa pun $^{23}$.

Cara pemanfaatan menu Kolom Soal bisa disesuaikan dengan penilaian harian yaitu manakala sudah menyelesaikan satu subtema atau satu tema ketika membuat penilaian akhir (evaluasi). Menu Kolom Soal bisa pula digunakan guru untuk mencari referensi dalam membuat lembar kerja siswa, soal ulangan da mengajukan pertanyaan langsung ketika pembelajaran berlangsung untuk memancing siswa untuk berpikir kritis. Sedangkan menu Kolom Soal merupakan kumpulan soal-soal berdasarkan suatu topik tertetu beserta pembahasannya.

Dalam hasil observasi yang dilakukan, pemanfaatan keempat menu tersebut bisa dikombinasikan selama proses pembelajaran berlangsung, tetapi bisa juga diterapkan secara mandiri khusus satu menu saja. Dalam menerapkan pembelajaran berbasis WAG yang memanfaatkan menu Video, BSE dan Kolom Soal secara otomatis guru akan bereksperimen dengan berbagai model pembelajaran yang sesuai dengan topik. Model pembelajaran dengan media daring yang digunakan oleh guru kelas VI telah menunjukkan pembelajaran yang interaktif, di mana pada proses pembelajaran lebih berpusat pada siswa . Pemanfaatan konten dalam proses pembelajaran menunjukkan adanya pengalaman belajar yang berbeda bagi siswa di masing-masing pertemuan. Siswa merasa tertarik, semangat dan senang selama kegiatan pembelajaran berlangsung.

22 Iis Dewi Lestari, 'Peranan Guru Dalam Penggunaan Media Pembelajaran Berbasis Information And Communication Technology (ICT) Di SDN RRI Cisalak', SAP (Susunan Artikel Pendidikan), 3.2 (2018), 137-42 <https://doi.org/10.30998/sap.v3i2.3033>.

${ }^{23}$ Nanik Sugiarti Willy Arif Indhaka, Eko Supraptono, 'Penerapan Buku Sekolah Elektronik Berbasis Android Dalam Materi Ajar Besaran Dan Satuan', Didaktikum: Jurnal Penelitian Tindakan Kelas, 17.2 (2016), $1-8$. 
Setelah melakukan observasi dan wawancara kepada keempat guru tersebut, diperoleh hasil langkah-langkah yang mesti dilakukan oleh guru dalam memanfaatkan WAG (WhatsApp Group) sebagai model pembelajaran daring, yaitu:

1. Perencanaan

Semua guru yang terlibat atau yang bertanggung jawab untuk mengisi pembelajaran jarak jauh harus terencana dengan baik dan matang seperti merumuskan tujuan belajar, memilih strategi belajar, dan berinisiatif belajar dengan atau tanpa bantuan orang lain.

2. Persiapan

Guru perlu melakukan persiapan secara matang sebelum menggunakan WAG (WhatsApp Group) sebagai model pembelajaran daring di kelas. Persiapan yang dilakukan guru seperti mempersiapkan RPP (Rencana Pelaksanaan Pembelajaran) dan silabus, menentukan topik pembelajaran yang akan disampaikan kemudian mencari materi tersebut dalam menu yang tersedia dalam WAG (WhatsApp Group), dan menentukan model pembelajaran yang akan dipakai. Setelah menemukan menu dan materi yang sesuai dengan tujuan pembelajaran, guru juga perlu mempersiapkan LKPD (Lembar Kerja Siswa ) dan perangkat TIK sebelum kegiatan pembelajaran berlangsung seperti handphone atau laptop.

3. Pelaksanaan

Pelaksanaan proses pembelajaran yang dilakukan berdasarkan hasil observasi di kelas MI Nurul Iman Sindet Lami Besuk yang peneliti lakukan adalah sebagai berikut:

a. Pendahuluan

Pada kegiatan pendahuluan pembelajaran dimulai dengan salam dan doa. Setelah itu guru melakukan absensi dan kegiatan literasi seperti hafalan surah pendek dan doa harian, membaca buku bacaan, menyanyikan lagu nasional, menyanyikan lagu mars PPK dan sebagainya. Guru melakukan apersepsi berupa tanya jawab berkaitan dengan materi yang telah dipelajari. Kemudian guru menyampaikan topik pembelajaran.

b. Inti 
Pada kegiatan inti guru menampilkan video pembelajaran atau gambar pada BSE. Guru dan siswa bersama-sama untuk menyimak video yang ditampilakan. Setelah menyaksikan video, guru dan siswa melakukan tanya jawab berkaitan dengan video yang sudah disaksikan. Guru memberikan bimbingan dan penjelasan kepada siswa. Guru kemudian memberikan tugas jika siswa sudah benar-benar memahami materi. Guru menjelaskan tugas yang harus dikerjakan siswa serta membagikan LKPD-nya melalui google drive.

Usai mendengarkan arahan dan bimbingan dari guru untuk menyelesaikan tugas berupa proyek. Siswa menjelaskan jawaban pada LKPD yang telah disediakan di google drive. Setelah siswa menyelesaikan tugasnya, masingmasing siswa mempresentasikan hasil belajarnya di WAG. Kemudian guru memberikan apresiasi dan penguatan terhadap jawaban yang disampaikan oleh siswa .

c. Penutup

Kegiatan pembelajaran dipungkasi dengan menarik kesimpulan bersamasama sampai waktunya pergantian jam pelajaran tiba. Tugas siswa yang tidak dapat diselesaikan di madrasah boleh dilanjutkan ketika di rumah.

Setelah dikaji, berbagai metode yang digunakan oleh guru dalam memanfaatkan WAG (WhatsApp Group) sebagai model pembelajaran daring pada saat proses pembelajaran dapat dikelompokkan sebagai berikut (Eni, 2021):

1. Pendahuluan

Pada bagian pertama ini guru mengucapkan salam pembuka yang disusul dengan absensi siswa untuk memastika siswa nya sudah siap menerima pelajaran online.

2. Demonstrasi

Kegiatan pembelajaran dengan metode demonstrasi dilakuan oleh guru untuk menjelaskan materi-materi yang sifatnya umum dan teoritis seperti pada materi Pendidikan Kewarganegaraan, Sejarah Nasional, siklus makhluk hidup. Guru menjelaskan materi melalui video, gambar, atau audio sesuai dengan topik pembelajaran yang dipelajari dan tersedia dalam WAG. Perangkat yang 
digunakan guru dapat berupa handphone, laptop dan LCD proyektor. Selanjutnya guru memberi tugas kepada siswa nya.

3. Diskusi

Melalui metode diskusi, guru berusaha meningkatkan pemahaman siswa terhadap materi yang dipelajari. Di awal pembelajaran guru dapat penjelasan yang terdapat dalam BSE atau menayangkan sebuah video kemudian memberi tugas untuk menyelesaikan lembar kerja yang telah diberikan guru lalu mempresentasikan hasil diskusi.

4. Tugas Individu

Metode pembelajaran ini bertujuan untuk meningkatkan pemahaman siswa secara mandiri. Setelah menyaksikan video pembelajaran atau penjelasan guru, siswa diberikan tugas tertulis yang harus dikerjakan secara individu/mandiri. Tugas yang diberikan bisa berupa tugas di luar jam pelajaran.

Dari penjelasan di atas, kemandirian belajar siswa merupakan kegiatan yang terdorong oleh suatu kemauan, pilihan serta tanggung jawab sendiri tanpa menggantungkan diri terhadap orang lain. Pendidikan Jarak Jauh tersebut merupakan bentuk pendidikan yang memberikan kesempatan kepada pembelajarnya untuk belajar secara terpisah dari pengajarnya ${ }^{24}$. Namun ada kemungkinan untuk acara pertemuan antara pengajar dan pembelajar hanya dilakukan kalau ada peristiwa yang istimewa atau untuk melakukan tugas-tugas tertentu saja.

Dengan pembelajaran jarak jauh, siswa tidak terkendala waktu dan tempat di mana mereka bisa mengikuti pembelajaran dari rumah masing-masing maupun dari tempat di mana saja mereka berada. Dengan pembelajaran jarak jauh, guru memberikan materi melalui WAG (WhatsApp Group) sebagai media pembelajaran yang efektif, yang bisa diakses di mana pun dan kapan pun tidak terikat oleh ruang dan waktu. Keadaan ini membuat siswa bisa secara leluasa memilih mata pelajaran yang dikuti dan tugas mana yang harus dikerjakan terlebih dahulu.

${ }^{24}$ Irzan Tahar, 'Hubungan Kemandirian Belajar Dan Hasil Belajar Pada Pendidikan Jarak Jauh', Jurnal Pendidikan Terbuka Dan Jarak Jauh, 7.2 (2006), 91-101. 


\section{KESIMPULAN}

Dari hasil penelitian dan pembahasan yang telah dijabarkan bisa diambil beberapa kesimpulan. Pertama, menu-menu dalam WAG (WhatsApp Group) yang sering dimanfaatkan oleh guru dalam proses pembelajaran di kelas yaitu BSE (Buku Sekolah Elektronik) dan juga memuat Kolom Soal. Sementara untuk menu lainnya guru belum pernah mencoba dalam proses pembelajaran karena masih dalam tahapan mempelajari lebih lanjut dan merencanakan sesuai dengan materi yang dibutuhkan pada pembelajaran. Kedua, penerapan pembelajaran dengan memanfaatkan WAG (WhatsApp Group) sebagai model pembelajaran daring di madrasah ibtidaiyah mempunyai langkah-langkah yang sama pada masing-masing guru. Langkah yang dilakukan guru yaitu dimulai dari persiapan dan pelaksanaan pembelajaran yang memuat kegiatan perencanaan, pembuka, inti dan penutup pembelajaran. Kemandirian belajar siswa semakin terlihat dengan layanan WAG yang disediakan oleh lembaga dengan melibatkan seluruh komponen lembaga.

Implikasi pembelajaran jarak jauh di madrasah menjadi solusi terbaik bagi semua guru dalam melaksanakan pembelajaran dan sangat kondusif pada masa pandemic covid19.

\section{DAFTAR PUSTAKA}

Azzahra, Nadia Fairuza, 'Mengkaji Hambatan Pembelajaran Jarak Jauh Di Indonesia Di Masa Pandemi Covid-19', Center for Indonesia Policy Studies, 2020

Baharun, Hasan, Chusnul Muali, Muhammad Mushfi, El Iq, Fathor Rozi, Nafisatur Rodiah, and others, 'Learning Strategies for Mobile-Assisted Seamless Learning: A Students 'Initial Perceptions', 536.Icsteir 2020 (2021), 557-60

Basar, Afip Miftahul, 'Problematika Pembelajaran Jarak Jauh Pada Masa Pandemi Covid19', Edunesia: Jurnal Imiah Pendidikan, 2021 <https://doi.org/10.51276/edu.v2i1.112>

Chaidar, Husain, 'Pemanfaatan Teknologi Informasi Dan Komunikasi Dalam Pembelajaran Di SMA Muhammadiyah Tarakan', Jurnal Kebijakan Dan Pengembangan Pendidikan, 2.2 (2014), 184-92

Creswell, J W, 'Creswell, J.W. (2003). Chapter One, “A Framework for Design.”, Research Design Qualitative Quantitative and Mixed Methods Approaches, 2003 <https://doi.org/10.3109/08941939.2012.723954>

Cucus, Ahmad, and Yuthsi Aprilinda, 'Pengembangan E-Learning Berbasis Multimedia Untuk Efektivitas Pembelajaran Jarak Jauh', Explore: Jurnal Sistem Informasi Dan 
Telematika, 2016 <https://doi.org/10.36448/jsit.v7i1.765>

Hidayat, Dede Rahmat, Ana Rohaya, Fildzah Nadine, and Hary Ramadhan, 'KEMANDIRIAN BELAJAR SISWA DALAM PEMBELAJARAN DARING PADA MASA PANDEMI COVID -19 Program Studi Bimbingan Dan Konseling, Universitas Negeri Jakarta SELF-REGULATED LEARNING OF STUDENTS STUDYING ONLINE', PERSPEKTIF Ilmu Pendidikan, 2020

Jusuf, Heni, Ahmad Sobari, and Mohamad Fathoni, 'Pengaruh Pembelajaran Jarak Jauh Bagi Siswa SMA Di Era Covid-19', Jurnal Kajian Ilmiah, 2020 <https://doi.org/10.31599/jki.v1i1.212>

Knowles, Malcolm S, 'THE MODERN PRACTICE OF ADULT EDUCATION, From Pedagogy to Andragogy What Is Andragogy ?', Business, 1980

Kusuma, Dianne Amor, 'DAMPAK PENERAPAN PEMBELAJARAN DARING TERHADAP KEMANDIRIAN BELAJAR (SELF-REGULATED LEARNING) MAHASISWA PADA MATA KULIAH GEOMETRI SELAMA PEMBELAJARAN JARAK JAUH DI MASA PANDEMI COVID-19', Teorema: Teori Dan Riset Matematika, 2020 <https://doi.org/10.25157/teorema.v5i2.3504>

Lestari, Iis Dewi, 'Peranan Guru Dalam Penggunaan Media Pembelajaran Berbasis Information And Communication Technology (ICT) Di SDN RRI Cisalak', SAP (Susunan Artikel Pendidikan), $3.2 \quad$ (2018), $137-42$ <https://doi.org/10.30998/sap.v3i2.3033>

Mulyani, Tri, 'STRATEGI PEMBELAJARAN JARAK JAUH SISWA BERKEBUTUHAN KHUSUS DI SD INKLUSI ERA PANDEMI COVID-19', ELEMENTARY: Islamic Teacher Journal, 2020

Nabila Hilmy Zhafira, Yenny Ertika, Chairiyaton, 'Pembelajaran Jarak Jauh Di Masa Pandemi', Jurnal l Bisnis Dan Kajian Strategi Manajemen, 2020

Napitupulu, Rodame Monitorir, 'Dampak Pandemi Covid-19 Terhadap Kepuasan Pembelajaran Jarak Jauh', Jurnal Inovasi Teknologi Pendidikan, 2020 <https://doi.org/10.21831/jitp.v7i1.32771>

Prawiyogi, Anggy Giri, Andri Purwanugraha, Ghulam Fakhry, and Marwan Firmansyah, 'Efektifitas Pembelajaran Jarak Jauh Terhadap Pembelajaran Siswa Di SDIT Cendekia Purwakarta', Jurnal Pendidikan Dasar, 2020

Rahmawati, Yeni, 'Penerapan Model Pembelajaran Berbasis Masalah Untuk Meningkatkan Kemandirian Belajar Siswa', Fondatia, 1.1 (2017), 68-91 <https://doi.org/10.36088/fondatia.v1i1.89>

Sadikin, Ali, and Afreni Hamidah, 'Pembelajaran Daring Di Tengah Wabah Covid19:(Online Learning in the Middle of the Covid-19 Pandemic)', BIODIK: Jurnal Ilmiah Pendidikan Biologi, 2020

Sari, D R, and F Amrozi, 'Analisis Efektivitas Pembelajaran Jarak Jauh (PJJ) Di Politeknik Penerbangan Surabaya', Jurnal Penelitian, 2020

Suharwoto, Gatot, 'Pembelajaran Online Di Tengah Pandemi Covid-19, Tantangan Yang Mendewasakan', Times Indonesia, 2020

Sulastrini, Sulastrini, and Muslihati Muslihati, 'Rancangan Implementasi Kemandirian 
Belajar Dalam Konteks Pandemi Covid-19 Berdasarkan Perspektif Freedom to Learn Rogers', Prosiding Seminar Bimbingan Dan Konseling, 2020

Sungkono, Sungkono, 'PEMBELAJARAN JARAK JAUH BERBASIS TEKNOLOGI INFORMASI', MAJALAH ILMLAH PEMBELAJARAN, 2005

Tahar, Irzan, 'Hubungan Kemandirian Belajar Dan Hasil Belajar Pada Pendidikan Jarak Jauh', Jurnal Pendidikan Terbuka Dan Jarak Jauh, 7.2 (2006), 91-101

Willy Arif Indhaka, Eko Supraptono, Nanik Sugiarti, 'Penerapan Buku Sekolah Elektronik Berbasis Android Dalam Materi Ajar Besaran Dan Satuan', Didaktikum: Jurnal Penelitian Tindakan Kelas, 17.2 (2016), 1-8

ZULFIKAR, Z, 'Rekonstruksi Pendidikan Keluarga Pada Masa Pandemi (Studi Pada Walimurid SMPI Al Hasanah Kota Bengkulu)', Annizom, 2020 